\title{
Motivational dynamics in English classes at a Brazilian public school
}

\section{Dinâmicas motivacionais em aulas de inglês em uma escola pública brasileira}

Raquel Bambirra*

CEFET-MG - Federal Center of Technological Education of Minas Gerais

Belo Horizonte, Minas Gerais, Brazil

\begin{abstract}
This paper seeks to discuss the interrelations between the motivation of an English teacher at a public federal high school in Brazil and that of her students from a dynamic systems perspective. Three teachers' oral narratives and 14 students' logbook entries were used for the data analysis. The teacher's descriptions and comments on her pedagogical practice were compared to the students' impressions and motivational levels in an attempt to understand this English classroom-system motivational dynamics and self-organization processes, focusing on how this teacher's and her students' motivation co-adapt and soft-assemble, influencing and being influenced by the context. The results seem to confirm not only that student motivation and teacher motivation are deeply interrelated, but also that they interact organically and continually, revealing that the context is contingent.
\end{abstract}

KEYWORDS: motivational dynamics, co-adaptation, soft-assembly, English classes, Brazilian public school.

RESUMO: Este artigo pretende discutir a inter-relação entre a motivação de uma professora de inglês de uma escola pública federal de nível médio do Brasil e a de seus estudantes sob a perspectiva dos sistemas dinâmicos complexos. Com base em três narrativas orais e 14 entradas de diário, a prática pedagógica da professora foi descrita e seus comentários comparados às impressões dos estudantes, em uma tentativa de compreender a dinâmica motivacional e os processos de auto-organização dessa sala de aula enquanto sistema, focando em como a motivação da professora e a dos estudantes se coadaptam e assumem configurações temporárias, influenciando e sendo influenciadas pelo contexto. Os resultados parecem confirmar não somente que a motivação da professora e a motivação dos estudantes estão profundamente inter-relacionadas, mas também que elas interagem orgânica e continuamente, revelando que o contexto é contingencial.

PALAVRAS-CHAVE: dinâmica motivacional, coadaptação, soft-assembly, aulas de língua inglesa, escola pública brasileira.

\footnotetext{
$\overline{\text { * raquelbambirra@gmail.com }}$
} 


\section{Introduction}

In this study, the English classroom is seen as a complex dynamic system (CDS) (LARSEN-FREEMAN; CAMERON, 2008; BURNS; KNOX, 2011; PAIVA, 2013). It is dynamic, because it is not static, but rather in constant change. It is complex due to the fact that its behavior is not linear and has emergent qualities; it derives from the interrelation of all of the system's elements, and therefore cannot be predicted nor reduced to individual components (LARSEN-FREEMAN, 2011). In turn, motivation has also been conceptualized as a CDS (DÖRNYEI; USHIODA, 2009; PAIVA, 2011; DÖRNYEI; USHIODA, 2012; DÖRNYEI, 2014).

Dörnyei, MacIntyre, and Henry (2015) observed that, by the end of the 2010s, there was a growing academic research production on second language acquisition within the complex dynamic system perspective, most of which was theoretical in nature. According to these researchers, there is a need for the production of empirical research guided by a CDS approach. Seeking to fill this gap, this article is interested in discussing the interrelation between a teacher's motivation and her students' motivation. The three elements - teacher motivation, student motivation, and context - are seen as dynamic systems themselves in continuous interplay with each other inside the English classroom system (DÖRNYEI; USHIODA, 2011; PAIVA, 2011; WANINGE, DÖRNYEI; DE BOT, 2014).

From a CDS perspective, any phenomenon is studied ecologically, taking into account the organic interrelation of the systems and processes involved in it. ${ }^{1}$ According to Lantolf (2000, p. 25),

in an ecological approach, because everything is connected to everything else, one cannot look at any single entity in isolation from the others without compromising the integrity of the very processes one is trying to understand and foment. ${ }^{2}$

Ushioda (2015) agrees that ecological perspectives are very useful in providing a holistic approach in order to understand processes taking place inside systems as well as those deriving from the interrelation of systems and contexts.

\footnotetext{
${ }^{1}$ van Lier's perspective (2000, p. 246).

2 Aligned with this belief, see also de Bot and Larsen-Freeman (2011, p. 18); Dörnyei, MacIntyre and Henry (2015, p.2); among other researchers interested in doing research in a dynamic systems perspective.
} 
According to Larsen-Freeman and Cameron (2008), research inspired by complexity theory ${ }^{3}$ does not investigate and analyze causal relations among single variables, as in traditional scientific research. Instead, as de Bot et al. (2013) state, causal relations simply do not exist within CDSs. In their words: "rather, there are always multiple interacting variables that make the process of development unpredictable to a greater or lesser degree" (p. 202).

Some studies have argued that there is an intrinsic relation between teachers' and students' motivation without establishing linear cause-effect explanations to the observed phenomena (DÖRNYEI; CSIZER, 1998; DÖRNYEI, 2003; DÖRNYEI; USHIODA, 2011; MATSUMOTO, 2009; WIESMAN, 2012; MISFUD, 2011; XIAO, 2014; LAMB; WEDELL, 2013; 2015).

Dörnyei and Csizer (1998) argued that teachers' behavior, personality, and teaching style influence the students' engagement in class. Dörnyei (2003, p. 26), defended that "the teacher's motivation has significant bearings on students' motivational disposition." Obviously, the students' motivation also influences the teachers', as they are reciprocal processes. In the context of task motivation, Dörnyei and Ushioda (2011) observed that the students' enthusiasm is boosted if they recognize their teacher's enthusiasm.

Matsumoto (2009) concluded that there exists a positive correlation between students' motivation to learn and their perception of teachers' commitment to teach. Similarly, Wiesman (2012, p. 107) realized that "when teachers truly care $(. .$.$) when teachers show empathy, students are more$ likely to develop academic goals."

Misfud (2011) claims to be the first who managed to establish an empirical link between teacher and student motivation. Using a mixed method approach, the researcher collected some data with a survey methodological design: two questionnaires, one answered by 34 teachers and another by 612 students in Malta, measured the participants' motivational levels and the relation between them. Then, this effort was complemented with the application of an interview about the motivation to teach and its possible relationship with the motivation to learn, responded by 12 teachers selected randomly from those who participated in the survey. The researcher

\footnotetext{
${ }^{3}$ In this article, the terms complexity theory and dynamic systems theory will be used interchangeably, based on Lantolf (2006), de Bot (2008), Larsen-Freeman and Cameron (2008), Larsen-Freeman (2011), de Bot et al. (2013), among others.
} 
managed to find out two factors that link and increase motivation to teach and to learn English as a foreign language: (1) a good teacher-student rapport and (2) high teacher efficacy.

In the distance learning context, Xiao (2014) used interviews to investigate the motivation of language tutors by looking at student-related factors and tutors' personal factors. The guiding questions were related to the ways in which students influenced their tutors' motivation to teach, to what extent the tutors' motivation was influenced by self-related factors, and how the tutors dealt with demotivating influence. In line with other research results, the author concluded that there is a clear and reciprocal interplay between student motivation and teacher motivation.

Finally, Lamb and Wedell (2015) reported that an intrinsic motivation to teach allowed the participant-teachers in their study to provide what these researchers call an 'inspiring teaching'. By inspiring teaching, Lamb and Wedell $(2013 ; 2015$, p. 7) refer to a teaching that fosters "longer-term changes in learners' attitudes, feelings and behavior in relation to studying the L2", and enhances their disposition to continue learning beyond the classroom, in an autonomous way.

Inspired by these and other contributions, and recognizing that motivation cannot be studied in isolation from the sociocultural context since, above all, it is a socially mediated process (USHIODA, 2003), ${ }^{4}$ this study intended to investigate motivational dynamics in Brazilian English classes at a public school. To operationalize this intent, it was necessary to delimit the systems under study having in mind that CDS boundaries are subtle, tenuous, and under constant change due to changes in other parts of the system (MERCER, 2013).

According to Checkland and Poulter (2006), and Foster-Fishman et al. (2007) apud Hargreaves (2010, p. 6-7), “'one way to determine a system’s boundaries is to identify a problem of interest and to ask who or what is involved in addressing the problem, has influence on the problem, or is influenced by it." Mercer (2013) endorsed this idea by citing Larsen-

\footnotetext{
${ }^{4}$ According to Ushioda (2003, p. 92), "the motivation to learn is also in this sense socially and culturally mediated. It is not located solely within the individual, but is socially distributed, created within cultural systems of activities involving the mediation of other human beings (RUEDA; MOLL, 1994, p. 131). [...] As Good and Brophy (1997, p. 238) emphasize, interest resides in people rather than in topics or activities, and motivation develops as a result of interactions among persons, tasks and larger environmental contexts."
} 
Freeman's suggestion that system boundaries are delimited, considering the purpose of the study, and identifying a "functioning whole" of interest. In the case of this study, the functioning whole is the set of motivational dynamics involved in the interrelation of the agents' (teachers' and students') motivation and the context.

Taking Schumann's (2015, p. xvi) words into account, to study L2 motivational dynamics, one should consider that

the individual is the entity of concern, and case studies become recognized as the appropriate level of granularity for understanding motivation trajectories in SLA. [...] Variation within and across individuals becomes central in a dynamic systems approach.

For the scope of this research, the English classroom was taken as a complex system, the teacher's and each learner's motivation are considered its subsystems.

Looking closely at these sub-systems, it is clear that they nest many other subsystems, such as "a dynamic constellation of cognitive, affective, motivational and behavioral characteristics in constant evolving interaction with one another" (USHIODA, 2015, p. 50). Based on Ushioda's (2015) conceptualization of context, all of the elements that influence teachers' and learners' motivation will constitute aspects of the context. In this study, context is considered to be everything that is on the periphery of the researcher's focus of observation.

Larsen-Freeman (2015) points out that the CDS theory has introduced the ideas of dynamism and emergence to modern scholarship. It means that "change and emergence are central to any understanding of complex dynamic systems" (p. 11). Because these systems are adaptive, they tend toward an equilibrium by means of self-organization.

Self-organization "refers to any set of processes in which order emerges from the interaction of the components of the system without direction from external factors and without a plan of the order embedded in an individual component" (LARSEN-FREEMAN, 2015, p. 13). In other words, the elements or subsystems "learn and co-evolve as they interact with one another and respond to changes in their environment" (HARGREAVES, 2010, p. 5).

The processes through which a complex system dynamically adapts to changes in context, changing itself from a previous configuration to 
another, is called soft-assembly. Language development ${ }^{5}$ takes place through soft-assembly and co-adaptation processes (LARSEN-FREEMAN, 2011). According to Larsen-Freeman (2011, p. 54), the context contributes "by affording possibilities for co-adaptation between interlocutors." It has a salient importance to language development because "local adaptations to contextual conditions usually generate emergent change" (LARSENFREEMAN; CAMERON, 2008, p. 204).

In the following section, the theory related to dynamic systems selforganization, more specifically to co-adaptation and soft-assembly in second language development, will then be revisited to support the data analysis. As Paiva (2011) verified, motivation is among the most important elements favoring system change and self-organization.

\section{Theory}

Complexity theory is interested in relations among elements of a system and/or among its subsystems. As situated realities, due to their everchanging nature, these elements or subsystems influence and are influenced by the context they are part of at a specific time. In addition, each subsystem encompasses other subsystems that interact with one another, influencing and being influenced by each other and the whole system.

The relations among systems and subsystems are treated in terms of co-adaptation. The term describes "a kind of mutual causality, in which change in one system leads to change in another system connected to it, and this mutual influencing continues over time" (LARSEN-FREEMAN; CAMERON, 2008, p. 202).

\subsection{Co-adaptation}

Larsen-Freeman and Cameron (2008) explain that systems are interconnected, can be nested into one another, exist at different levels of granularity, and operate at different timescales. Further, "there is not just one system and its environment, there is a multitude of systems

\footnotetext{
${ }^{5}$ The term second language development will be preferred to second language acquisition, since we agree with Larsen-Freeman (2011) that a second language is never totally acquired, but rather, it is an endless process of learning and self-improvement.
} 
evolving simultaneously, partially autonomously, partially in interaction" (HEYLIGHEN apud LARSEN-FREEMAN, 2011, p. 51). Among the many subsystems evolving inside the English classroom system, the teachers' motivation and the students' motivation must be focused on if L2 motivation is at stake, as is the case of this study.

According to de Bot et al. (2013), timescales must be observed for the study of language development. A change at the millisecond scale may have an impact on the scale of seconds, days, years, and so on. Likewise, larger time scales affect language processing at the millisecond level. These researchers (ibid.) also stress that learning cannot be separated from social dynamics and conditions. In their words, "human activity and development form an ensemble process that plays out along a brain-body-world continuum" (DE BOT et al., 2013, p. 205). Hence, they suggest a dynamic system theory approach to the study of second language development since it "emphasizes the critical importance of both spatial and temporal dynamics" (p. 203). When looking more closely at motivational dynamics in more than one class, these granularities must be taken into consideration, since they are agents of the co-adaptation process.

As mentioned before, according to complexity researchers (DE BOT, 2008; LARSEN-FREEMAN, 2011; DE BOT et al., 2013), DST is about change and its focus is on development over time. Larsen-Freeman (2011) states that changes occur in dynamic systems due to instability, as they operate under conditions that are not in equilibrium: temporarily stable patterns become unstable, leading the system to seek self-organization. According to Kramsch (2012, p. 12), "when you add one piece, the rest changes and the whole thing needs to be resignified and restructured." For this reason, processes are of more interest to research than outcomes (LARSEN-FREEMAN, 2011).

Change is inherent to every complex system, because (1) its interacting elements or agents are always internally changing, (2) they change the way they interact from time to time, or even (3) they suffer influences from interconnected systems (LARSEN-FREEMAN; CAMERON, 2008). Kramsch (2012, p. 12) summarizes: "the systems adapt both through interaction with the environment and through internal reorganization/selforganization." It suggests that co-adaptation naturally happens continually.

Context is not a backdrop or a scenario for language learning. It is a system itself, which "includes the physical, social, cognitive, and cultural" 
(LARSEN-FREEMAN; CAMERON, 2008, p. 204), in interaction with other systems involved in a specific language learning situation or system. In Mercer's (2013, p. 377) words, "typically, contexts or the environment, which are themselves conceptualized as systems, are not viewed as external variables affecting a system from outside, but rather [are considered to be] integral parts of the system." ${ }^{\circ}$ Due to its nature, context is contingent in a dynamic system perspective, and its relationship with the other elements of a system, or with another system, is one of interdependency (LARSENFREEMAN, 2015).

Considering the continual presence of change, the process of selforganization and the context contingency, the concept of soft-assembly becomes central.

\subsection{Soft-assembly}

Soft-assembly is the process through which a system changes from one temporary configuration to another, in response to the influence of contextual factors that disturb its current order, imposing imbalance. This kind of circumstance leads to change, as the dynamic systems tend toward self-organization (DE BOT, 2008). de Bot, Lowie and Verspoor (2007) explain that a developing system "is in constant complex interaction with its environment and internal sources. Its multiple interacting components produce one or many self-organized equilibrium points, whose form and stability depend on the system's constraints" (p. 14).

Larsen-Freeman (2011, p. 49) concludes that "language, its use, and its acquisition are mutually constitutive, simply occurring at different levels of ecological scale - individual through speech community - and timescale." This implies that the continuous relation of co-adaptation among agents (or subsystems) at individual levels within the classroom-system - the teacher and his/her students - allows for the emergence of the lesson. Therefore, the motivational dynamics that take place in a classroom emerge from the interaction of teachers, students, and contexts, through processes of coadaptation. In Ushioda's (2009, p. 2015) words, ${ }^{7}$ motivation emerges from

\footnotetext{
${ }^{6}$ In line with Larsen-Freeman and Cameron (2008), Ushioda (2009), Kramsh (2012), Larsen-Freeman (2011), Burns and Knox (2011), de Bot et al. (2013), and many others who conceive the L2 classroom as a dynamic system.

${ }^{7}$ According to the researcher, "a person-in-context relational view of motivation."
} 
"relations between real persons, with particular social identities, and the unfolding cultural context of activity."

\section{Method}

Due to the nature of the investigated phenomena, and the situated perspective of dynamic systems (which aggregates context and temporal dimension to the observed event), the present study focuses on the interactions between the motivation of a teacher and that of her students to access motivational dynamics in English classes at a secondary school.

Using a qualitative case study methodological design, the teacher's narratives about her motivation and daily practice, together with students' impressions of their self-motivational levels, were used to understand how teacher's pedagogical choices influenced and were influenced by students' impressions and moods, as well as to appreciate how elements of the context determined and were determined by the interactions taking place.

\subsection{Location of data collection and participants}

Data were collected during a school semester (from March 9 to July 10,2015 , over a 20 -week period) at a very traditional public institution that offers technical and technological courses in Brazil, from high school to post-graduate studies.

The participant teacher is a 36-year-old, experienced, committed professional, who has been teaching English in Brazil for about 10 years. Academically guided, she teaches enthusiastically. As advised, she has freely chosen a group of students in the $2^{\text {nd }}$ year of high school, approximately 16-18 years of age, who voluntarily accepted to take part in this study.

At this institution, English is taught in weekly classes of one hour and forty minutes, with a maximum of 20 students per group. The objective is to enhance the students' chances to actively engage in classroom activities, interact more with their peers, and receive a more individualized assistance from the teacher. The group chosen by this teacher to take part in this research had 16 students.

Following guidelines suggested by the institution's Coordination of Foreign Languages, the teacher adopted a communicative approach via textual genres. This means that she privileged one or two textual genres selected by the Coordination as the main topics to be taught and, from them, 
explained the language and the grammar. The group was asked to produce an oral and a written register of the specific textual genres, mostly in groups, over a two-month period. During the first two months (March and April), the students were supposed to create an infographic chart and present it to the whole group. During the last two months (May and June), the two textual genres to be produced were a curriculum vitae and a job interview.

\subsection{Procedures for data collection}

Data collection involved the following steps:

Step 1: Collection of the teacher's teaching narratives

At the end of each class (once a week), a short narrative (5 to 10 minutes) was digitally recorded. To avoid losing focus or forgetting to mention important aspects of each class, she was given five written prompts to help her perform this narrative: (1) description of your planned class; (2) evaluation of the accomplishment of your plans; (3) indication of any factors that may have influenced this class; (4) expression of your level of satisfaction with this specific class, and, optionally, (5) registration of anything else you consider relevant.

\section{Step 2: Collection of students' impressions on their self-motivational levels}

At the beginning and the end of each class, the students were asked to register their impressions about their motivational levels for that class. Each student was given a logbook with a collection of colorful stickers to do this job. To make sure the students' impressions and comments would remain unknown by the teacher, they were asked to create a pseudonym and insert it on the first page of the logbook, as shown in Figure 1, together with the course and group identification. 
FIGURE 1 - First page of the logbook

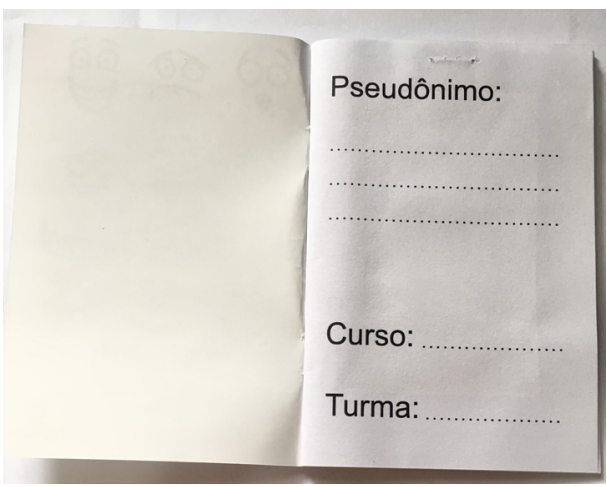

The teacher was not to be told their pseudonyms. She was responsible for keeping the students' logbooks in a folder provided by the researcher inside her locker during the data collection process. Each class day, she was expected to take this folder to the classroom and spread the logbooks on a table so that each student could get his/hers. At the end of the class, the logbooks would be put back into the folder at random by the students, and the teacher would take it to her locker.

The logbook, as shown in Figure 2, had 20 pages, as it was made to last a school semester, which usually consists of 20 English classes.

FIGURE 2 - Smiley face stickers and logbook

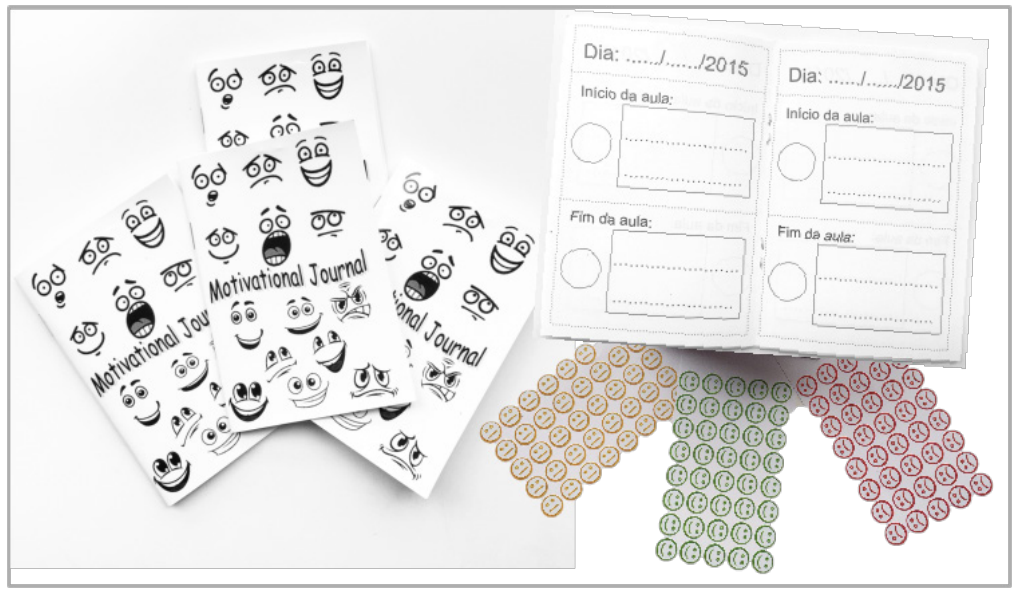

At the top of each page, a class date should be entered. Below the date, each page showed two distinct areas to be filled in, corresponding to 
the beginning and the end of that class. The students would stick a smiley face inside the circles and justify his/her choices for those chosen smiley faces inside the rectangle in front of each sticker. The smiley faces were:

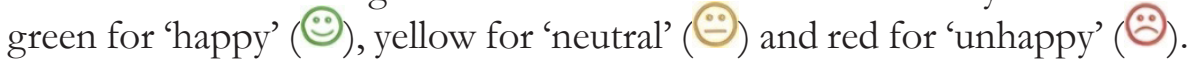

On the very first day of class, the researcher distributed the logbooks and explained to the students that, when selecting a smiley face to stick, they should think of their motivational level for that class, at the beginning of it, and their motivational level at the end of the class. It was also made clear that they were not supposed to relate the faces to their emotions but to how motivated they were feeling at the moment they would choose them.

They did not have to justify their choices if they chose a 'happy' (-) or a 'neutral' (-) smiley face; however, they were expected to justify their choice each time they used an 'unhappy' face (-). In this case they were supposed to explain why they felt demotivated by writing key words, phrases or simple sentences, as they wished, in the rectangular area in front of the corresponding circle. With this procedure, the students managed to assess their motivation at the beginning of each class and when they left the room at the end.

\subsection{Defining classes to be analyzed}

The focus of this paper is on motivational dynamics, so it was assumed that the classes which had more events of change in students' motivation would probably involve more events of co-adaptation and soft-assembly.

It seemed that the best timescale to take would probably be all the 14 classes taught by this teacher during that school semester. However, since the method of analysis included (a) the description of each class from the teacher's point of view and her appraisal of her and the students' motivational levels, (b) the interrelation of this information with the students' comments and declared motivational levels, together with (c) the identification of events of co-adaptation and soft-assembly, it was decided that the appropriate timescale for this paper should be limited to the three classes in which the students declared having changed their motivational levels by choosing 'unhappy faces' (= demotivated) and 'neutral faces' (= amotivated $\left.{ }^{8}\right)$ to 'happy faces' (= motivated).

\footnotetext{
${ }^{8}$ The terms demotivation/demotivated and amotivation/amotivated were borrowed from Dörnyei \& Ushioda (2011, p. 138-140).
} 
The criteria to calculate these changes and select the chosen classes were:

$1^{\text {st: }}$ to look for those classes with major incidence of number of students choosing 'happy' at the end of the class (HE) minus the number of students choosing 'happy' before class (HB): HE-HB;

$2^{\text {nd. }}$ : to verify the proportion of the number of students present and the incidence of 'happy faces' at each day. In this way, each class was assigned a percentage that represents the measure of change in students' motivational levels. Only then was it possible to compare classes.

Table 1 shows the incidence of 'happy' moods in each class (HE - HB) and the percentage they represented as compared to the number of students who came to class and, consequently, filled in their logbooks. The classes chosen for analysis in this paper were highlighted in bold.

TABLE 1 - Change of students' motivation in each of the three classes

\begin{tabular}{|c|c|c|c|}
\hline \multicolumn{4}{|c|}{$\begin{array}{c}\text { GROUP } \\
\text { (teacher }+16 \text { students) }\end{array}$} \\
\hline Classes & $\begin{array}{c}\text { () } \\
(\mathrm{HE}-\mathrm{HB})\end{array}$ & $\begin{array}{c}\text { \# of students in } \\
\text { class }\end{array}$ & Change $\%$ \\
\hline 18/Mar & 9 & 14 & 64.3 \\
\hline 25/Mar & 6 & 13 & 46.2 \\
\hline 1/Apr & 1 & 10 & 10.0 \\
\hline 8/Apr & 2 & 14 & 14.3 \\
\hline 15/Apr & 2 & 15 & 13.3 \\
\hline 29/Apr & 4 & 14 & 28.6 \\
\hline 6/May & 0 & 11 & 0.0 \\
\hline 13/May & 3 & 15 & 20.0 \\
\hline 20/May & 2 & 15 & 13.3 \\
\hline 27/May & 3 & 9 & 33.3 \\
\hline 3/Jun & 1 & 13 & 7.7 \\
\hline 10/Jun & -1 & 12 & 8.3 \\
\hline 17/Jun & 3 & 14 & 21.4 \\
\hline 24/Jun & 0 & 2 & 0.0 \\
\hline 1/Jul & 1 & 8 & 12.5 \\
\hline 8/Jul & 2 & 13 & 15.4 \\
\hline
\end{tabular}


Finally, it is important to mention that, although the students' reported levels of motivation on the first day of class were the most positive $(64.3 \%$, as shown in Table 1), it was not considered in this analysis, because it was not a typical one - the teacher had an informal conversation in L1 with the students, aiming to present herself, get to know them a little better, and present the content of the course, her pedagogical approach, the assessment process, and so on.

Thus, the classes chosen to be analyzed were March 25, May 27, and April 29. This means that the corpus of analysis was compounded by three oral narratives: each one corresponding to a class to be analyzed, and 14 logbook entries made by the 16 students, at the beginning and end of each class.

\subsection{Procedures for analyzing the data}

This study adopted the method of dynamic description, proposed by Larsen-Freeman (2011, p. 63), for studying CDSs. According to this method,

the researcher accepts the fact that change in one system can produce change in other connected systems, attempts to describe the interconnected web of factors influencing change, and investigates processes of co-adaptation in response to changed pedagogic goals.

According to Larsen-Freeman (2011), complexity theory calls for retrodiction rather than prediction. ${ }^{9}$ Larsen-Freeman (2011, p. 61) states:

What we can observe in language development is what has already changed - the trajectory of the system. This is a "trace" of the real system, from which we try to reconstruct the elements, interactions, and developmental processes of the system.

The teacher's narratives were guided by the five prompts, described in section 3.2. To analyze these, the three chosen classes were described, emphasizing the teacher's comments on the development of the classes and the students' general response, at a first moment. Then, the students' impressions to the classes, reported in their 'motivational journals' (section 3.2), were compared to their teacher's comments and pedagogical choices. Finally, events of co-adaptation and soft-assembly were identified by

\footnotetext{
${ }^{9}$ On the same subject, please see Dörnyei (2014).
} 
comparing changes in the classroom system mentioned by the teacher and the information provided by the students - their motivational levels and comments.

\subsection{Ethical concerns}

All of the participants received detailed information about the research project, and their voluntary acceptance to participate was confirmed by means of a Consent Form, which they signed before data collection. Because the students were under age, parental consent was also requested.

Many efforts were implemented to assure the participants' anonymity during data collection and analysis, as described in section 3.2.

Although the participants were assured the right to leave the research project at any time, no one chose to do so. They were also given the opportunity to see the collected data and receive explanation on the ways they could be analyzed, but only the teacher was interested in this information.

\section{Results and discussion}

Based on the data provided by the students, Table 2 shows how their motivation evolved throughout the investigated classes. Assuming that the three moods represent a progressive scale from not motivated (= 'unhappy' -2 ) to motivated (= 'happy' $)^{-}$), it is possible to realize that the students tended to alter their moods, choosing a smiley face that showed they were more motivated at the end of these classes.

TABLE 2 - Students' motivational move in the investigated classes

\begin{tabular}{|c|c|c|c|c|c|c|}
\hline \multicolumn{7}{|c|}{ Group 1} \\
\hline \multirow[b]{2}{*}{ Classes } & \multicolumn{3}{|c|}{ Before class } & \multicolumn{3}{|c|}{ After class } \\
\hline & 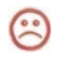 & $\ominus$ & () & ஜ & $\ominus$ & •) \\
\hline March 25 & 1 & 4 & 8 & - & - & 13 \\
\hline April 29 & 4 & 5 & 5 & 3 & 2 & 9 \\
\hline May 27 & - & 4 & 5 & - & 1 & 8 \\
\hline
\end{tabular}


Having contextualized the teacher's pedagogical approach (section 3.2), the results are discussed in the remainder of this text, organized by class dates. The teacher will now be referred to as T1.

\subsection{Class of March 25}

On March 25, T1 asked the students to take turns and present the results of an informal research on infographic charts that they were supposed to have done as homework. Using the data show projector, they explained the main characteristics of infographic charts, based on a checklist created by the Coordination and provided earlier by the teacher. They discussed many examples of the genre with their colleagues. By choosing this classroom dynamic, T1 shared the responsibility to teach with the students, giving them the chance to play an active role in their own learning.

The presentations were made in English and the teacher appreciated their proficiency levels. She observed, though, that she would have to work with them on how to proceed in delivering oral presentations, because they tended to lose the focus quite easily and did not properly contemplate their audience, establishing eye contact, not putting their all into it, speaking at an inadequate voice volume and tone, etc.

After, she asked the students to open their textbooks to do one listening and one reading task on the ways people deal with social media nowadays. However, according to her, they did not seem to be in the mood for those activities. She commented that they could no longer concentrate, that they were talking too much, excited about a natural discussion that had emerged about social networks, and so she decided to change her class plan and invest in guiding their discussion, rather than insist on breaking their rhythm and working with the textbook (unpredictability and adaptation). She explained that she would later need the vocabulary and grammar involved in those conversations, which was the same involved in the previously planned listening and reading tasks. An excerpt from T1's oral narrative illustrates this point:

After presenting their research on infographics, I was expecting to work with exercises on the textbook. I would have some 20 to 25 minutes before the end of the class. It would be time enough to do the planned tasks but the group was so demotivated for them... they were not in the mood, really. They just wanted to talk about social networks and solve a polemic discussion they had just started. So I changed my planning on the spot. I preferred to follow their rbythm and capitalize on what they wanted to do. (our emphasis) 
Trying to confirm if a process of co-adaptation leading to motivation really occurred at the end of this class, as can be inferred from T1's narrative, the data provided by the students were checked.

There were not enough data to explain exactly why and how these students had changed their moods during class, because they did not leave comments in their logbooks explaining all their choices. Nevertheless, because their initial motives for choosing 'unhappy' were contextual factors, it is reasonable to infer that when they interacted within the classroom system (with T1 and their peers) they changed and adapted to it, in a demonstration that the systems tend to self-organize (DE BOT, 2008).

Verifying the students' comments and the smiley faces used at the beginning of the class, we find that two students were not feeling well: "I have woken up late and am still tired" (), "I'm sick" (๑). But all the others had chosen 'happy' (-) as their initial mood. One was apprehensive, because he/she had not done the assigned homework, and two students mentioned the teacher was beautiful. T1 concluded her narrative, complaining that the students arrived late for this class (on March 25). Their classes started at 7 a.m. but some students got there 30 to 40 minutes late, and she could not tell why. Maybe these initial moods and comments can explain that.

At the end of the class, the two students who had arrived feeling bad were fine and the one who was apprehensive was fine as well. These changes in their moods may indicate that soft-assembly processes have taken place. Somehow, during the class, the students moved to a new temporary state in terms of motivation, i.e., they soft-assembled (LOWIE; VERSPOOR, 2007).

Figure 2 represents this co-adaptation process lived by T1 and her students in this class, related to motivation. An unexpected event (students' demotivation) led to change, which influenced the entire system. 
FIGURE 2 - Co-adaptation process leading to motivation on March 25

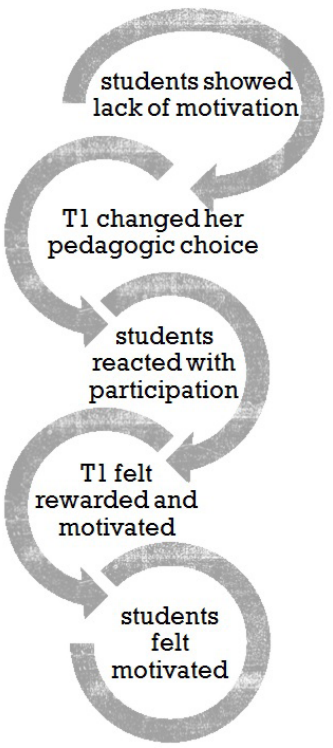

The only comment found in a logbook at the end of this class was that the teacher was really beautiful (-) . This lack of comments can be explained by the fact that they were only supposed to leave notes when they chose the mood 'unhappy' (-). By the end of the class, everyone had changed their moods to 'happy' (-) , in a clear demonstration that T1 had taken the right decision when she abandoned her class plan and let the students determine how they would cover the content she needed to cover, i.e. vocabulary and grammar items. Instead of working on the textbook, she decided to simply guide their discussion, make the most of it, promoting their agency and autonomy development, which they found to be motivating. It is also possible to conclude that the group has soft-assembled. The group changed its initial motivational configuration - that from the beginning of the class to a new one - seen at the end of the class, as a consequence of the mutual influencing processes lived by the agents (students and teacher) while coadapting during class.

\subsection{Class of April 29}

On April 29, T1 asked the group to work on written exercises proposed by the textbook, in pairs or individually, at their will, while she would give them oral feedback on the written version of the infographic 
charts each pair had created thus far. They were supposed to bring their production to class in a flash drive, already revised by at least one colleague. T1 would call each pair of students at a time and analyze their infographic charts in terms of layout, linguistic and rhetoric movements, use of nonverbal elements, vocabulary choice and grammatical aspects, based on the checklist elaborated by the Coordination.

She commented: "their production was excellent, of a great quality, and I enjoyed the way they were interacting with me, defending their choices during the feedback sessions." She also proudly mentioned that "although they were free to choose the themes for their infographic charts, most of them had chosen something related to violence over the internet, prejudice against minorities, lack of tolerance, and so on, showing they are not afraid to reflect and position themselves."

According to Table 2, there were four students 'unhappy' (:), five 'neutral' (-) and five 'happy' (-) before class. At the end, there were three 'unhappy' (ْ), two 'neutral (-) and nine 'happy' (-) . Checking the students' comments on their logbooks, five comments were relative to the beginning of the class and three to the end of it.

At the beginning, the four comments made bv students who had chosen the 'unhappy' mood said: "I'm really tired." (ஜ), "I arrived late and the gorgeous teacher is nervous." (2), "a friend's mother has died" (ஜ), and "I'm sick" (ஜ). Besides these, there was one made by a student who had chosen the "happy' mood and it said: "work presentation" (-).

All these comments made at the beginning of the class signal evidence that contextual factors prior to that moment might have influenced the emergence of learning at the level of these students-systems, and the emergence of the whole lesson at the level of the group - the classroom system (LARSEN-FREEMAN, 2011), since they might have influenced co-adaptation processes taking place during the class.

In this sense, the student who entered the words 'work presentation' in his logbook choosing the mood 'happy' (-), showing that s/he had arrived motivated and eager to present his/her oral production, for some unknown reason, got tense and this feeling influenced his/her performance, given that, at the end of the class, s/he changed his/her mood for 'unhappy' and wrote: "Got very nervous in class. Insane!" (¿).

On the other hand, two other students were still 'unhappy' at the end of the class. They expressed it by repeating their initial comments: "a 
friend's mother has died" and "still sick". This repetition may indicate that these comments were conceptualized by the students as reasons why they did not change their initial mood.

Finally, the one who arrived 'unhappy' saying s/he was late and the teacher was nervous $\left({ }^{\circ}\right)$, declared at the end of the class that $\mathrm{s} /$ he was 'neutral' (-) because his/her book was incomplete. It seems possible to infer that, in terms of motivation, this student could soft-assemble-adjust to the new context found inside the classroom and change his/her initial mood, leaving the classroom a little better than s/ he had arrived (DE BOT, 2008).

\subsection{Class of May 27}

On May 27, T1 started the class with a listening task. The students were asked to listen to an interview with Kelly Clarkson, the famous singer, and answer some questions on it proposed by the textbook. In T1's words:

They [the students] were having a considerable difficulty to follow the interview because it was at a normal speed, kind of fast for them, and the order of the questions proposed by the textbook was different from the order the information appeared in the interview. So, I started helping them and they managed to do the task successfully. (our emphasis)

It seems that $\mathrm{T} 1$ offers the scaffolding they need in a natural way, enhancing or diminishing her role according to their needs (OHTA, 2000). This attitude has probably protected their self-esteem (DÖRNYEI, 2009; DÖRNYEI; USHIODA, 2009) and promoted motivation, since they were able to fulfill the task despite their difficulties (DÖRNYEI, 2001; DÖRNYEI; MACINTYRE; HENRY, 2015).

After, they delved naturally into a speaking task, also from the textbook, in which they were supposed to discuss society's current beauty standards. T1 said the participation was intense. In her words:

Well..., I just asked them to speak only in English. (...) and that was the cool part: they all participated in English!, the subject was so polemic, even those who have more difficulties with the language felt like sharing their ideas. I showed them I was excited and everyone participated. This group is great! (our emphasis) 
Then, she proposed a pronunciation task on ways to pronounce the suffix -ed of verbs in the past. According to T1, that was a more mechanical task that brought the students some focus and discipline. Taking advantage of that, she systematized the structure and use of the simple past, a verb tense that they had just studied, by comparing it to the simple present, a verb tense that they already knew, and introduced the present perfect tense, showing the difference in use between the simple past and the present perfect, as they would need these three verb tenses to compose and perform their interviews. To finish the class, she performed an oral exercise with them on a grammar point proposed by the textbook and asked them to do it in writing as homework. T1 said:

That [the pronunciation task. was a more mechanical task that demanded attention and rbythm from them and so it brought them some focus and discipline. When we finished, they were calm and concentrated. However, three students didn't really know when to use the simple past or the present perfect yet. As I still had some time, I changed plans and, instead of dismissing them, I went to the blackboard to systematize this grammar point. I don't like to focus on grammar, but sometimes I have the impression they are just asking for it. After doing so, we still found the time and energy to do orally a grammar exercise from the textbook. Great! (our emphasis)

Looking at the comments left in the students' logbooks, the information on Table 2 is confirmed: at the beginning of the class there were four 'neutral' (-) moods and five 'happy' (-); by the end of it, only one neutral (-) and eight 'happy' (-).

Although there are only three comments at the beginning of the class, two are very positive: "I got here early and I am excited!", "My teacher gets more beautiful each day!". Another student, who chose the 'neutral' mood, attested a contextual factor saying s/he was "late for class, feeling tired" ( -). By means of soft-assembly, somehow this tiredness was overcome (or forgotten) by the end of the class.

Two comments related to the end of this class were found and they said: "I participated a lot, the subject was funny.", and "It's unbelievable how beautiful she [the teacher] is."

Once again, the data provided by the students confirm the teacher's narrative. It is possible to notice that co-adaptation processes between T1 and her students, as well as between T1's motivation and that of her students', are co-constructed at every moment, in class (LARSEN-FREEMAN, 2011). 
During the listening task, a demand for scaffolding from the part of the students led to change, which affected the whole classroom system. During the speaking task, the teacher's empathy has led to change, again affecting the whole system. And finally, during the pronunciation task, an unexpected behavior from the students led to a change in T1's behavior, determining a novel way to end this class. These are examples of co-adaptation processes related to motivation identified on May 27, at each of the three tasks lived by T1 and her students. They are represented in Figure 3.



On May 27, T1 observed that only 9 students were present. It was a national holiday eve and she assumed that was the reason the other seven students had not gone to school. Despite complaining about the students arriving late for class (on March 25) and about their being absent on May 27, T1 ended up satisfied with all three classes, mainly due to the students' participation. This seems to be her main indicator of success. In her words:

I did not manage to fulfill all my plan for this class but they were so involved, talking so much all the proposed topics and some more that I was happy in the end. We don't have total control of our classes, that's a fact (on March 25).

Each student commented on his/ her infographic while I was giving them my feedback on theirproduction. I was glad to see that they had clearpositions and reflected critically on the messages they were trying to convey (on April 29).

I showed them I was excited and everyone participated (on May 27). 
It seems possible to believe that the more T1 feels 'happy' (-) with her students' participation, the more they participate. In addition, the more she shows she is proud of them when they reflect and contribute ideas, when they position themselves enacting their identities, the more they take an active and critical role in class (USHIODA, 2011).

It is interesting how much T1 is sensitive to her group. The classes flow naturally, because she perceives and respects the students' responses. Just as she had done on March 25, influenced by her students' behavior, T1 also changed her class plan on May 27. It seems that respecting the students' rhythm is an efficient strategy she often uses to keep them motivated in and for her classes (DÖRNYEI; USHIODA, 2011).

T1 strongly invests in critical literacy, based on the pedagogy of multiliteracies (KALANTZIS; COPE, 2012). On March 25, she had the group discuss social networks, their use and abuse, and on May 27, about society's beauty standards. During T1's narrative about the class on May 27, she said: "this subject [the LGBT causes] is really important to me" and "I'm glad they could realize that society imposes standards to each gender."

The strength of T1's pedagogical practice seems to emerge, to a large extent, from her disposition to feel her students' needs and moods, and negotiate with them, explicitly or not, not only the classroom atmosphere, but also how the group covers the subjects and even when, which fosters autonomy development (DÖRNYEI; USHIODA, 2011). She is not selfcentered when teaching and facilitates their learning by respecting their individualities and differences (DÖRNYEI, 2005; DÖRNYEI; USHIODA, 2011), thus fostering participation and the development of their citizenship (KALANTZIS; COPE, 2012).

\section{Conclusion}

It seems relevant to remember that the teacher was chosen to participate in this study not only because she has volunteered to do so, but mainly because she is well respected in her school and the pupils report appreciating her classes. This circumstance has most likely influenced the results of this research, since T1 seems to be an inspiring teacher, according to Lamb and Wedell's (2015) motivational perspective. I believe the results would have been very different if the students were not so fond of T1. Hence, this should be taken into consideration in the development of further research. 
This study corroborated that students' and their teacher's motivation are deeply interrelated (MISFUD, 2011). One influenced and was influenced by the other all the time. This seems to be the most significant contribution of the study, when considering its implications for pedagogical practices. Therefore, if teachers want to have motivated students in class, they must first rest assured that they are genuinely motivated to teach and work on protecting their own motivation along the way (MISFUD, 2011; LAMB; WEDELL, 2015).

It was possible to realize that the lesson emerges from the coadaptation processes lived by the teacher and the students inside the classroom and, for this reason, it is out of the teachers' control (PAIVA, 2011). It was possible to verify that the lesson, as well as learning, evolved unpredictably, from mutual influencing motivational processes (and surely many others) among the elements of the system, involving negotiation and co-construction (LARSEN-FREEMAN, 2011).

The data made it evident that co-adaptation emerged from the interrelation among the teacher, the students, and the context. This interrelation is continuous, and it may lead both to motivation or to demotivation (USHIODA, 2003).

It was also possible to perceive that the context is contingent, and it constantly influences and is influenced by the other elements of the system (MERCER, 2013; USHIODA, 2015). Unfortunately, what seems to be a limitation of this study is that, although the students registered in their logbooks many contextual factors influencing their engagement, participation, and co-adaptation, the data were not sufficiently detailed to support a deeper discussion about cases of soft-assembly, be it at individual levels (at the students' systems levels) or at the level of the group (at the classroom system level).

Finally, it would be very interesting if further research on events of co-adaptation and soft-assembly taking place in Brazilian English classrooms could go beyond the identification of their occurrence, as was the case of this study, and report more deeply on describing and discussing them with the support of a richer amount of data collected with the teachers and the students involved, proposing more systemic representations of the dynamic and complex character of these events. 


\section{Acknowledgement}

I am thankful to Dr. Martin Lamb for contributing immensely to my academic growth. I am also thankful to the anonymous reviewers of this journal for their competent and generous feedback. Finally, I am grateful to the Brazilian agency CAPES (Coordenação de Aperfeiçoamento de Pessoal de Nivel Superior) for financing this research project.

\section{References}

BURNS, A.; KNOX, J. S. Classrooms as complex adaptive systems: a relational model. The Electronic Journal for English as a Second Language, TESL-EJ, v. 15, n. 1, p. 1-25, 2011.

CHECKLAND, P. B.; POULTER, J. Learning for action: a short definitive account of soft systems methodology and its use for practitioners, teachers, and students. Chichester: John Wiley, 2006.

DE BOT, K. Introduction: second language development as a dynamic process. The Modern Language Journal, Wiley Online Library, v. 92, n. 2, p. 166-187, 2008.

DE BOT, K.; LOWIE, W.; VESPOOR, M. A dynamic systems theory approach to second language acquisition. Bilingualism: Language and Cognition, Cambridge Press, v. 10, p. 7-21, 2007.

DE BOT, K.; LOWIE, W.; THORNE, S. L.; VESPOOR, M. Dynamic Systems Theory as a theory of second language development. In: MAYO, M.; GUTIERREZ-MANGADO, M.; ADRIÁN, M. (Org.). Contemporary approaches to second language acquisition. Amsterdam: John Benjamins, 2013. p. $199-220$.

DÖRNYEI, Z.; CSIZÉR, K. Ten commandments for motivating language learners: results of an empirical study. Language Teaching Research, v. 2, n. 3, p. 203-229, 1998. DÖRNYEI, Z. Motivation to learn a foreign/second language. In: DÖRNYEI, Z. (Org.). Teaching and researching motivation. Harlow: Longman, 2001. p. 46-100.

DÖRNYEI, Z. Attitudes, orientations, and motivations in language learning: advances in theory, research, and applications. In: DÖRNYEI, Z. (Org.). Attitudes, orientations and motivations in language learning. Oxford: Blackwell, 2003. p. 3-32.

DÖRNYEI, Z. The psychology of the language learner: individual differences in second language acquisition. Mahwah: Lawrence Erlbaum Associates, Publishers, 2005.

DÖRNYEI, Z. The L2 motivational self-system. In: DÖRNYEI, Z.; USHIODA, E. (Org.). Motivation, language identity and the L2 self. Bristol: Multilingual Matters, 2009. p. 9-42. 
DÖRNYEI, Z. Researching complex dynamic systems: 'Retrodictive qualitative modelling' in the language classroom. Language Teaching, Sage Journals, v. 47, n. 1, p. 80-91, 2014.

DÖRNYEI, Z.; MACINTYRE, P. D.; HENRY, A. Introduction: applying Complex dynamic systems principles to empirical research on $\mathrm{L} 2$ motivation. In: DÖRNYEI, Z.; MACINTYRE, P. D.; HENRY, A. (Org.). Motivational dynamics in language learning. Bristol: Multilingual Matters, 2015. p. 1-7.

DÖRNYEI, Z.; USHIODA, E. Motivation, language identities, and the L2 self: a theoretical overview. In: DÖRNYEI, Z.; USHIODA, E. (Org.). Motivation, language identity and the L2 self. Bristol: Multilingual Matters, 2009. p. 1-8.

DÖRNYEI, Z.; USHIODA, E. Motivation, language identities and the L2 self: future research directions. In: DÖRNYEI, Z.; USHIODA, E. (Org.). Motivation, language identity and the L2 self. Bristol: Multilingual Matters, 2009. p. 350-356.

DÖRNYEI, Z.; USHIODA, E. Teaching and researching motivation. 2. ed. Harlow, England: Pearson Longman, 2011.

DÖRNYEI, Z.; USHIODA, E. Motivation. 2012. Available at: <http://www. zoltandornyei.co.uk/uploads/2012-ushioda-dornyei-rhsla.pdf $>$. Retrieved in Nov 2014.

FOSTER-FISHMAN, P.; NOWELL, B.; YANG, H. Putting the system back into systems change: a framework for understanding and changing organizational and community systems. American Journal of Community Psychology, Wiley Online Library, v. 39, p. 197-215, 2007.

HARGREAVES, M. (Org.). Evaluating system change: a planning guide. Princeton, NJ: Mathematica Policy Research, 2010. p. 1-20.

KALANTZIS, M.; COPE, B. Literacies. New York: Cambridge University Press, 2012.

KRAMSCH, C. Why is everyone so excited about complexity theory in Applied Linguistics? Mélanges CRAPEL, INALF - CNRS, n. 33, numéro special: Didactique de langues et complexité: en homage à Richard Duda, p. 9-24, 2012.

LAMB, M.; WEDELL, M. Inspiring English teachers: a comparative study of learner perceptions of inspirational teaching. ELT Research Papers, 13-03, 2013. Available at: <https://www.teachingenglish.org.uk/sites/teacheng/files/C684\%20 Inspiring\%20English\%20Teachers_WEB_FINAL_V2.pdf>. Retrieved in: Jul 2015.

LAMB, M.; WEDELL, M. Cultural contrasts and commonalities in inspiring language teaching. Language Teaching Research, Sage Journals, v. 19, n. 2, p. 207-224, 2015. 
LANTOLF, J. P. (Ed.) Sociocultural theory and second language learning. Oxford: Oxford University Press, 2000.

LANTOLF, J. P. Language emergence: implications for Applied Linguistics - a sociocultural perspective. Applied Linguistics, Oxford Academic, v. 27, n. 4, p. 717728, 2006.

LARSEN-FREEMAN, D. A complexity theory approach to second language development/acquisition. In: ATKINSON, D. (Org.). Alternative approaches to second language acquisition. Abingdon: Routledge, 2011. p. 48-72.

LARSEN-FREEMAN, D.; CAMERON, L. Research methodology on language development from a complex systems perspective. The Modern Language Journal, Wiley Online Library, v. 92, n. 2, p. 200-213, 2008.

MATSUMOTO, M. Second language learner's motivation and their perceptions of teachers' motivation. In: INTERNATIONAL CONFERENCE ON TEACHING AND LEARNING IN HIGHER EDUCATION, 2., 2009, Kuala Lumpur, Malaysia. Proceedings... Kuala Lumpur, Malaysia: Quality Learning in Higher Education, 2009. Available at: <http://epublications.bond.edu.au/hss_ pubs/348>. Retrieved in: July 2015.

MERCER, S. Towards a complexity-informed pedagogy for language learning. Revista Brasileira de Linguística Aplicada, Belo Horizonte, UFMG, v. 13, n. 2, p. 375398, 2013.

OHTA, A. S. Rethinking interaction in SLA: developmentally appropriate assistance in the zone of proximal development and the acquisition of L2 grammar. In: LANTOLF, J. P. (Org.). Sociocultural theory and second language learning. Oxford: Oxford University Press, 2000. p. 51-78.

PAIVA, V. L. M. O. Identity, motivation and autonomy in second language acquisition from the perspective of complex adaptive systems. In: MURRAY, G.; GAO, X.; LAMB, T. (Org.). Identity, motivation and autonomy in language learning. Bristol: Multilingual Matters, 2011. p. 57-72.

PAIVA, V. L. M. O. Second language acquisition: reconciling theories. Open Journal of Applied Sciences, Scientific Research Publishing, v. 3, n. 7, p. 404-412, 2013.

SONG, B.; KIM, T-Y. Teacher (de)motivation from an activity theory perspective: cases of two experienced EFL teachers in South Korea. System, Elsevier, v. 57, p. 134-145, 2016.

USHIODA, E. Motivation as a socially mediated process. In: LITTLE, D.; RIDLEY, J.; USHIODA, E. (Org.). Learner autonomy in the foreign language classroom: teacher, learner, curriculum and assessment. Dublin: Authentik / Trinity College, 2003. p. 90-102. 
USHIODA, E. A person-in-context relational view of emergent motivation, self and identity. In: DÖRNYEI, Z.; USHIODA, E. (Org.). Motivation, language identity and the L2 self. Bristol: Multilingual Matters, 2009. p. 215-228.

USHIODA, E. Motivating learners to speak as themselves. In: MURRAY, G.; GAO, X.; LAMB, T. (Org.). Identity, motivation and autonomy in language learning. Bristol: Multilingual Matters, 2011. p. 11-24.

USHIODA, E. Context and complex dynamic systems theory. In: DÖRNYEI, Z.; MACINTYRE, P.; HENRY, A. (Org.). Motivational dynamics in language learning. Bristol: Multilingual Matters, 2015. p. 47-54.

VAN LIER, L. From input to affordance: social-interactive learning from an ecological perspective. In: LANTOLF, J. P. (Org.). Sociocultural theory and second language learning. Oxford: Oxford University Press, 2000. p. 245-259.

WANINGE, F; DÖRNYEI, Z.; DE BOT, K. Motivational Dynamics in Language Learning: Change, Stability, and Context. The Modern Language Journal, Wiley Online Library, v. 98, n. 3, p. 704-723, 2014.

WIESMAN, J. Student motivation and the alignment of teacher beliefs. The Clearing House: a Journal of Educational Strategies, Issues and Ideas, Taylor \& Francis Online, v. 85, n. 3, p. 102-108, 2012.

$\mathrm{XIAO}, \mathrm{J}$. What do distance language tutors say about teacher motivation? Open Learning, Routledge, v. 29, n. 2, p. 145-159, 2014.

Data de submissão: 15/08/2016. Data de aprovação: 05/05/2017. 